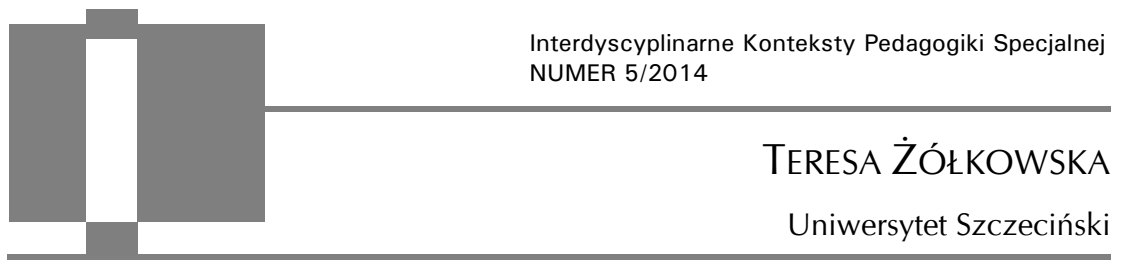

\title{
Dlaczego emancypacja osób niepełnosprawnych powinna być „pustym znaczącym"?
}

\begin{abstract}
Teresa, Why should the emancipation of disabled people (in Poland) be "an empty signifier"? [Dlaczego emancypacja osób niepełnosprawnych powinna być „pustym znaczącym”?]. Interdyscyplinarne Konteksty Pedagogiki Specjalnej, nr 5, Poznań 2014. Pp. 9-16. Adam Mickiewicz University Press. ISBN 978-83-2322866-0. ISSN 2300-391X.
\end{abstract}

The aim of this deliberation is the presentation of the theoretical basis of liberal democracy as explained by Ernesto Laclau. The conception, which in my opinion, is a useful tool to analyze the social-political situation of the Excluded (disabled) in Poland. From the different important dimensions of these situations, I focused on the search for theoretical justifications for emancipation. An issue which is probably the oldest and most often anylised social issue. Emancipation has still not lost its significance despite the changes which took place through the history in the sense of understanding this term and the fields to which emancipation refers. The issue of emancipation of the Excluded (disabled) as shown by Laclau I analyze in the context of theory of discourse and hegemony. This is due to the fact that I decided that both discourse and discursive conception of hegemony are the conditions of the possibility of existence of what is both social as well as a basis field of analysis of a social-political situation of the Excluded (disabled). By presenting the theoretical perspective by Laclau (discourse, empty signifier, hegemony, emancipation) I try to show that this perspective not only shows "the meaning framework thanks to which the social life my take place" but also the multicontextivity and diversification of the social issued and different possibilities of its interpretation. An important characteristic of this perspective is also the fact that it points out the need of trying to im- 
prove democracy. Like Laclau claims, "the moment of imagining of a desire is maybe more important than its accomplishing, because it is the moment that motivates us to action and initiates the creative thinking".

KEY WORDS: discourse, emancipation, empty signifiers, disability.

W swoim wystąpieniu chciałabym przedstawić problematykę Innego z perspektywy politycznej. "Inny” pod pojęciem, którym w dalszych swoich rozważaniach będę ujmować "Wykluczonego" z życia społeczno-politycznego, jest częstym podmiotem analiz w obszarze refleksji lewicowych, chociażby w teorii działań komunikacyjnych Jurgena Habermasa, koncepcji trzeciej drogi Anthony'ego Giddensa i Ulricha Becka czy teorii demokracji radykalnej Ernesta Laclau. Ten ostatni projekt pozwolę sobie przedstawić (w wielkim skrócie) w niniejszym artykule. Głównym powodem przywołania Laclau jest mała znajomość jego teorii polityki w Polsce, szczególnie w literaturze z zakresu pedagogiki specjalnej, oraz - jak sądzę - przydatność tej teorii dla analizy sytuacji Wykluczonych (osób niepełnosprawnych) z życia społeczno-politycznego w Polsce.

Ernesto Laclau to argentyński filozof wykładający teorię polityczną na Uniwersytecie w Essex. Jest przedstawicielem postmarksizmu, współtwórcą teorii demokracji radykalnej. W swojej twórczości odwołuje się do marksizmu (najczęściej poddaje go krytyce i dekonstrukcyjnemu odczytaniu). Wyraźnie odrzuca marksistowski dogmatyzm, a z samego marksizmu przyjmuje teorię hegemonii i emancypacji oraz kwestie dialektyki i antagonizmu społecznego. Stanowisko polityczne Laclau „można umieścić gdzieś pomiędzy liberalizmem a współczesnymi wersjami myślenia lewicowego, takimi jak komunitaryzm czy teoria krytyczna w wydaniu Habermasa" (Rasiński 2004, s. 10). Laclau próbuje łączyć wymienione podejścia - propaguje idee demokracji. Uważa, że nie można stworzyć idealnej demokracji, bowiem nie ma możliwości pozbycia się wszelkich wykluczeń. Stwierdza: „Każda polityka nieuchronnie 
produkuje niezadowolonych. Żaden system społeczno-polityczny nie jest na tyle rozciągły, żeby reagować na wszystkie potrzeby i roszczenia" (Butler, Laclau, Zizek 2000; Sepczyńska 2006, s. 284).

Laclau twierdzi, że wszystkie problemy społeczne należy rozpatrywać z perspektywy dyskursu. W swoich interpretacjach - wraz ze współautorką teorii Chantal Mouffe - bardzo szeroko ujmuje dyskurs. Ich teoria dyskursu jest teorią społeczną wyposażoną w zestaw adekwatnych założeń ontologicznych, epistemologicznych, metodologicznych i we właściwą im aparaturę pojęciową. Wspólnie definiują go jako konstruowany społecznie system pola znaczeniowego, system, który określa ramy kształtowania się tożsamości różnych przedmiotów i praktyk (Gąsior-Niemiec 2008; Laclau 2002). Laclau wskazuje, że tożsamość określają reguły dyskursu, czyli logika różnicy i logika równoważności. Logika różnicy to, jego zdaniem, mechanizm wytwarzania znaczenia (tożsamości) poprzez odróżnianie danego przedmiotu dyskursu od innych, które są dla niego obce i/lub antagonistyczne. Logika równoważności działa na odwrót: wzmacnia, upowszechnia oraz legitymizuje znaczenie (tożsamość) danego przedmiotu poprzez wytworzenie podobieństwa i w związku z innymi przedmiotami, które są znaczeniowo zbieżne (Laclau 2004a).

Można to wytłumaczyć w następujący sposób: tożsamość Wykluczonego kształtuje się jako różnica w stosunku do tego, co Typowe. Wykluczony będzie więc określany za pomocą cech różniących go od Typowego, czyli jako ktoś, kto nie ma pracy, jest biedny, samotny, uzależniony od innych (Kaliszewska, Żółkowska 2013). Wymienione cechy są równoważne pod względem tego, że wszystkie odróżniają Wykluczonych od Typowych. Tracą swój szczególny, różnicujący charakter, ponieważ każda $\mathrm{z}$ nich $\mathrm{w}$ podobny i równoważny sposób symbolizuje dla Wykluczonych coś odwrotnego, przeciwstawnego, zagrażającego - dominującą władzę Typowych. Można to też wytłumaczyć dzięki ujęciu pod pojęciem Wykluczonego różnych grup, np. niepełnosprawnych, grup etnicznych, ekologicznych, seksualnych, feministycznych, religijnych itd. Każda z nich różni się od pozostałych, ale w związku z logiką ekwiwalen- 
cji różnice te znoszą się i wszystkie grupy są traktowane jako jeden element systemu określany jako Wykluczony.

W swojej teorii Laclau przyjmuje też, że dyskurs jest systemem otwartym. W tym miejscu jego podejście różni się od stanowiska, które prezentował Ferdinand de Saussure, autor teorii języka wykorzystywanej przez Laclau przy tworzeniu teorii dyskursu (Rasiński 2010). De Saussure traktował język jako całość, jednolitą i zamkniętą, dla Laclau natomiast język jest otwartym systemem polegającym na stałym konstruowaniu oraz dekonstruowaniu znaczenia. Laclau podkreśla też, że warunek konieczny dla systemu znaczeniowego stanowią granice tego systemu (dyskursu, języka). Granice są niezbędne przy tworzeniu systemu, ponieważ jeżeli chcemy stworzyć system znaczeń z jakiegoś zbioru elementów, to musimy przenieść poza ten system to, co do niego nie należy. System znaczeń musi zajmować miejsce, poza którym istnieje coś, co nim nie jest, coś, co jawi się jako przeciwstawne dla systemu. W przypadku systemu znaczeniowego (dyskursu, języka) jego granice nie mogą być czymś oznaczanym, lecz muszą stanowić „zerwanie”, „załamanie”, koniec procesu oznaczania (Laclau 2002). Jak widać, przyjęcie przez Laclau tez o otwartości systemu umożliwia pojawienie się tego, co autor nazywa "pustymi znaczącymi”. Jego zdaniem, "puste znaczące to element znaczący bez elementu znaczonego", "to element sytemu, który nie ma treści” (2004 a, s. 67). Takim „pustym znaczącym” może być np. emancypacja - kategoria określająca Wykluczonego jako różniącego się od Typowego, ale unieważniająca różnice między poszczególnymi Wykluczonymi. Nie ma jednej uniwersalnej definicji emancypacji, ponieważ zmienia się ona wraz z czasem oraz miejscem i dla każdego oznacza coś innego. Rozumienie tego pojęcia będzie więc zależało od perspektywy tego, kto o nim mówi.

Laclau uważa, że należy dokonywać redefinicji emancypacji. Nowe podejście do emancypacji wyprowadza z koncepcji hegemonii połączonej ze współczesną teorią dyskursu. Jego zdaniem, współczesna emancypacja to obszar walk hegemonicznych. Warunkiem hegemonii czy - jak to określa - „stosunku hegemonicznego” są relacje pomiędzy uniwersalnością i partykularnością (Laclau 
2004b). Współczesna emancypacja to walka o przejęcie uniwersalizmów, które z jednej strony będą tym, „co wyklucza”, a z drugiej będą takimi "pustymi znaczącymi”, dającymi możliwość tworzenia wspólnoty w realizacji dalekosiężnych celów. Zdaniem Laclau, „uniwersalne cele jednoczące szeroki zbiór demokratycznych żądań nie mogą posiadać konkretnej treści. Jeżeli mają integrować grupy o różnych celach, to mogą być jedynie nazwą bądź symbolem braku" (Sepczyńska 2006, s. 286). Innymi słowy, emancypacja współczesnych Wykluczonych, takich jak: członkowie grup etnicznych, seksualnych, feministycznych, niepełnosprawni, to walka o przejecie "pustego znaczącego".

Zobaczmy na koniec, w jakim wymiarze koncepcja Laclau może być przydatna $w$ analizie sytuacji osób niepełnosprawnych w Polsce.

Po pierwsze - propozycja wykorzystania dyskursu. Wiemy, że takie próby były podejmowane i zakończyły się sukcesem, ponieważ wskazały zupełnie nowe obszary niepełnosprawności.

Po drugie - wykorzystanie reguł dyskursu (logiki różnicy i ekwiwalencji $w$ uzupełnieniu interpretacji dotyczących kształtowania się tożsamości osób niepełnosprawnych i sposobu percypowania tych osób przez Typowych).

Dalej - znalezienie czynników utrudniających osobom niepełnosprawnym walkę o wyjście z wykluczenia. Jednym z czynników, który określa czy wręcz pogłębia wykluczenie społeczne osób niepełnosprawnych, jest brak właściwej reprezentacji. Reprezentacje grup osób niepełnosprawnych nie były i nie są $\mathrm{w}$ chwili obecnej znaczącymi podmiotami dyskursu społeczno-politycznego. Uważa się je za "zbyt słabe" do podjęcia krytyki obecnego systemu, podważenia sztywnych, nieaktualnych schematów oraz stworzenia nowych idei, wspólnych dla wszystkich niepełnosprawnych. Przyczyn "słabości” reprezentacji osób niepełnosprawnych można doszukiwać się w czynnikach zewnętrznych, w ograniczaniu dostępu do dyskursu politycznego. Powszechna jest praktyka redukowania wpływów reprezentacji poprzez działania ekonomiczne, np. ograniczanie dotacji na działalność statutową, dostępu do pełnienia ważnych funkcji w organizacjach czy instytucjach publicznych, 
a nawet do korzystania $\mathrm{z}$ mediów. Reprezentację utrudniają też niewłaściwe działania rządu, np. resortowy podział zadań na rzecz osób niepełnosprawnych, realizacja tylko wybranych przedsięwzięć, często wyłącznie na rzecz określonych grup. Władze rządowe i samorządowe odchodzą od realizacji uniwersalizmów na rzecz działań specjalnych. Należą do nich m.in. różne programy dotyczące np. zakupu samochodów, komputerów itp., a także skierowane tylko do konkretnej grupy osób niepełnosprawnych, np. organizowanie szkoleń zawodowych dla pracowników zakładów aktywności zawodowej. W trakcie analizy działań z zakresu polityki na rzecz osób niepełnosprawnych można również dostrzec, że podmioty zaangażowane $\mathrm{w}$ kreowanie współczesnej sceny politycznej powiązanej z rynkiem wykorzystują swoje wpływy w celu blokowania zasad typowych dla państwa opiekuńczego, praw ochrony pracowników czy poszerzania sfery zabezpieczenia socjalnego lub opieki zdrowotnej. Sprzyjają temu ostre cięcia budżetowe, obniżające zdolność egzekucji prawa oraz opóźnianie regulacji prawnych. Okazuje się ponownie, że w sytuacji, kiedy najbardziej znaczącym czynnikiem jest rynek, nie podejmuje się, i to za zgodą społeczną, działań na rzecz walki o równość i sprawiedliwość społeczną.

Czynników „słabości” grupy osób niepełnosprawnych w dyskursie politycznym można się też doszukiwać w samej grupie. Obecnie dyskurs niepełnosprawności próbują prowadzić pojedyncze osoby niepełnosprawne, naukowcy, a także organizacje międzynarodowe i pozarządowe, choć te $\mathrm{z}$ reguły reprezentują interesy tylko części osób niepełnosprawnych (np. o danym rodzaju niepełnosprawności, korzystających z edukacji, poszukujących pracy itd.). Organizacje oraz fundacje reprezentujące osoby niepełnosprawne nie ucieleśniają więc bezpośrednio, jak ująłby to Laclau, „woli” wszystkich niepełnosprawnych, a większość ich działań ma charakter przygodny i tymczasowy. Mamy więc taką sytuację: nie realizuje się celów uniwersalnych, lecz tylko zamysły wąskiej grupy osób niepełnosprawnych czy też wyłącznie uczestników grupy reprezentującej, tych, którzy mają władzę. Zdaniem Laclau, takie odejście od uniwersalizmu nie jest właściwe, bowiem promowanie jedynie par- 
tykularnych interesów kończy się porażką. W takiej sytuacji wszystkie partykularyzmy okazują się ważne; sprzyja ona konfliktom pomiędzy grupami.

Pewnym wyjściem byłoby powstanie grupy, która mogłaby przekształcić swoje partykularne cele $\mathrm{w}$ uniwersalizm łączący wszystkie zespoły.

Być może takim uniwersalizmem - „pustym znaczącym” - mogłaby być emancypacja, jako kategoria, która unieważni różnice między Wykluczonymi (osobami niepełnosprawnymi), a jednocześnie określi tożsamość tych osób jako różniącą je od Typowych. Podkreślam takie rozumienie emancypacji, bowiem uważam, że tożsamość osoby niepełnosprawnej jest ważna i, choć różna od Typowej, to dla rozwoju człowieka niepełnosprawnego niezbędna. Moim zdaniem, $\mathrm{w}$ konstruowaniu dyskursu emancypacyjnego należy więc uwzględniać znaczenie, jakie ma dla każdego podmiotu poczucie własnej tożsamości, oraz dążyć do zapobiegania opresyjności społecznej. Trzeba więc poszukiwać czynników kształtujących tożsamość osoby niepełnosprawnej i jednocześnie określić możliwość eliminacji tych, które stwarzają wykluczenie. Wydaje się, że przy takim założeniu emancypacja jest możliwa, ale nie $\mathrm{w}$ sensie pełnym, całościowym. Chodzi o pokazanie sposobów kreowania i uskuteczniania działań demokratycznych, otworzenia się demokracji na różnice społeczne, na nowe podmioty, kolejne antagonizmy społeczne, konieczność uznania swobody w tworzeniu się zróżnicowanych układów społeczno-politycznych.

\section{Bibliografia}

BUtLeR J., Laclau E., ZizeK S., Contingency, Hegemony, Universality: Contemporary Dialogues on the Left, Versos, London 2000.

GĄSIOR-NIEMIEC A., Teoria dyskursu Laclau i Mouffe jako narzędzie analizy socjologicznej - przypadek dyskursu "osiedli grodzonych", [w:] Analiza dyskursu w socjologii i dla socjologii, red. A. Horolets, Wydawnictwo Adam Marszałek, Toruń 2008. 
KALISZEWSKA K., ŻÓŁKOWSKA T., The Social Construction of Social Identity of People with Intellectual Disability, "International Journal of Developmental Disabilities”, 2013, vol. 19, s. 1-15.

LAClaU E., Dlaczego puste znaczace maja znacznie dla polityki, [w:] Emancypacje, red. L. Kaczanowski, K. Liszka, Ł. Nysler, A. Orzechowski, L. Rasiński, A. Sypniewska, Wydawnictwo Naukowe Dolnośląskiej Szkoły Wyższej, Wrocław 2004a.

LaClaU E., Dyskurs, [w:] Przewodnik po wspótczesnej myśli politycznej, red. R. Goodin, P. Pettit, Książka i Wiedza, Warszawa 2002.

LACLAU E., Uniwersalizm, partykularyzm i problem tożsamości, [w:] Emancypacje, red. L. Kaczanowski, K. Liszka, Ł. Nysler, A. Orzechowski, L. Rasiński, A. Sypniewska, Wydawnictwo Naukowe Dolnośląskiej Szkoły Wyższej, Wrocław 2004b.

RASIŃSKI L., Dyskurs i władza. Zarys polityki agonistycznej, Wydawnictwo Naukowe Dolnośląskiej Szkoły Wyższej, Wrocław 2010.

RASIŃSKI L., Wstęp, [w:] E. Laclau, Emancypacje, Wydawnictwo Naukowe Dolnośląskiej Szkoły Wyższej Edukacji TWP, Wrocław 2004.

SEPCZYŃSKA D., Ernesto Laclau - postmarksistowska koncepcja wspólnoty politycznej, [w:] Z myśli hiszpańskiej i iberoamerykańskiej. Filozofia - literatura - mistyka, red. M. Jagłowski, D. Sepczyńska, Instytut Filozofii UWM, Olsztyn 2006. 